\title{
Removal of Organic Matter Using Phytoextraction Technique with the Heliconia psittacorum and Typha angustifolia Species in Swine Production Systems
}

\author{
Jesús Antonio Quintero Cardozo*, Gustavo Alberto Granados Zarta, Carlos Daniel López Nájera and Sergio Saúl Santos Martínez \\ Santa Lucia Research Center, University Institute of Peace-UNIPAZ, Km 14 via Barrancabermeja - Bucaramanga, path El Zarzal, Colombia \\ "Corresponding author: Jesús Antonio Quintero Cardozo, Santa Lucia Research Center, University Institute of Peace-UNIPAZ, Km 14 via Barrancabermeja - \\ Bucaramanga, path El Zarzal, Colombia, Tel: +506 2205-9000; E-mail: jesus.quintero@unipaz.edu.co
}

Rec date: February 24, 2018; Acc date: March 30, 2018; Pub date: March 31, 2018

Copyright: (c) 2018 Cardozo JAQ, et al. This is an open-access article distributed under the terms of the Creative Commons Attribution License, which permits unrestricted use, distribution, and reproduction in any medium, provided the original author and source are credited.

\begin{abstract}
Wastewater generated at the MVZ Academic Research Unit (NAIP), located at the University of La Paz in Barrancabermeja Santander. It was an environmental problem, due to the non-compliance with the values of the pollutant load.

For the NAIP, wastewater treatment, there was a conventional system, which was a septic tank, the heat was not at its peak, the lack of maintenance was evident and so the poor state in which it was. Therefore, it is urgent and necessary to fix and complement the system.

The methodology used in this project was based on the consultation of different sources of bibliographical information and field observation, in order to analyze everything related to the optimization process of the wastewater treatment system of the NAIP and generate positive solutions in Pro to minimize the environmental problem.
\end{abstract}

This project contemplated as the first phase, the evaluation of the initial state of the system, where parameters were analyzed in laboratory in accordance with Resolution 631 of 2015; These results show that this system improves the increase of the percentage of removal required by the environmental regulations, so that the optimization alternatives were proposed and implemented in the different stages of this treatment system, which plants are found in this work of degree.

After knowing the initial state of the treatment system, a pre-treatment was designed and implemented, which is a screening system, optimized and adapted to a septic tank to be used as a primary treatment, it now works as a sedimentation tank. And as a secondary treatment we proposed a biological alternative, which are two artificial subsurface flow wetlands in series with Heliconia psittacorum and Typha angustifolia, completing and complementing the conventional treatment system found.

Once the system is finished, follow the following respectful for five months, recording the adaptation of the plants, checking the operation of the tank and performing the cleaning of the screening system. At the end of this adaptation period, the following evaluation of the efficiency of the system was carried out, checking its decontamination range, which was $96 \%$ to $99 \%$ for removal of BOD5, COD, SST, SSED and GA; Obtaining decreases of DB5 and COD from $6280 \mathrm{mg} \mathrm{O} / \mathrm{L}$ and $13007 \mathrm{mg} \mathrm{O}_{2} / \mathrm{L}$ up to $25 \mathrm{mg} \mathrm{O} / \mathrm{L}$ and $67 \mathrm{mg} \mathrm{O}_{2} / \mathrm{L}$ (respectively).

Keywords: Phytoremediation; Emerging plants; Adsorption; Sedimentation; Bacterial metabolism

\section{Introduction}

The advance and development of the porcicola livestock industry in Colombia has been one of the most important activities for several decades [1]. This is due to the fact that it generates a great economic impact, thanks to its commercialization, and social since it fosters the generation of employment. This productive system generates, in turn, negative impacts on the water resource, due to the fact that the necessary measures or precautions are not taken for the correct management of the wastewater.
The high degree of pollution generated by pig farms is one of the main factors that contribute to the deterioration of soils, contamination of water sources and in general a risk to the health of man and his animals; mainly due to the volume, composition of both liquid and solid waste and the management systems with which these are treated.

The treatment of wastewater from pigs, and livestock in general, is an important factor in which they have focused their attention on different governmental and environmental agencies of global, national and local nature, which ensure the care and water resource protection; It is of vital importance that the places dedicated to this type of activity have an appropriate and efficient system for the reduction of the 
Citation: Cardozo JAQ, Zarta GAG, Nájera CDL, Martínez SSS (2018) Removal of Organic Matter Using Phytoextraction Technique with the Heliconia psittacorum and Typha angustifolia Species in Swine Production Systems. J Vet Sci Technol 9: 531. doi: $10.4172 / 2157-7579.1000531$

Page 2 of 5

pollutant load of the residual water, since these discharges are usually discharged to water sources or bodies.

In this research project, the development and implementation of different processes to optimize the wastewater treatment system of the Academic Porcine Investigation Unit of MVZ, located at the Universidad de la Paz in Barrancabermeja Santander, is presented which considerably benefit the environmental and social aspects of the area of influence.

\section{Materials and Methods}

The method used in the investigation was developed with the following sequence:

- Identification of the native species emerging from the study area with the help of the communities.

- Definition of the design factors of the biological system.

- Start-up of the experimental unit.

- Morphological description of the species in the system, for the determination of the adaptive capacity of the species.

- Experimental analysis of the effectiveness indices of the native emergent species used in the study saw. Determination of the removal rates of organic matter.

\section{Experimental design}

We worked on a factorial design that had as a response variable the concentration of organic matter (COD and BOD5) in the effluent; and as factors, the type of biological pattern (three levels: system with biological pattern 1. Scirpus californicus, system with biological pattern 2. Typha angustifolia and white control system) and the time of plant growth (observation during 3 months of growth). In addition, the $\mathrm{pH}$, conductivity and temperature were determined for the adaptive process in order to provide optimal conditions for the development of the seedlings in the system.

\section{Planting of seedlings and sampling}

50 young seedlings of the species used in the study were collected in their natural state. Ten seedlings with similar morphological characteristics were selected to be distributed in the system with biological pattern 1. Scirpus californicus, system with biological pattern 2. Typha angustifolia and white control system. Each of the seedlings was seeded in the system's filter bed (artificial subsurface flow wetland).

Subsequently the response variables were measured according to the following sampling plan day zero (0), two (2), four (4), eight (8), sixteen (16), and thirty (30), and control was carried out daily conductivity, $\mathrm{pH}$ and temperature parameters for 30 effective days.

The following Figure 1 shows the sequence of the experimental unit developed:

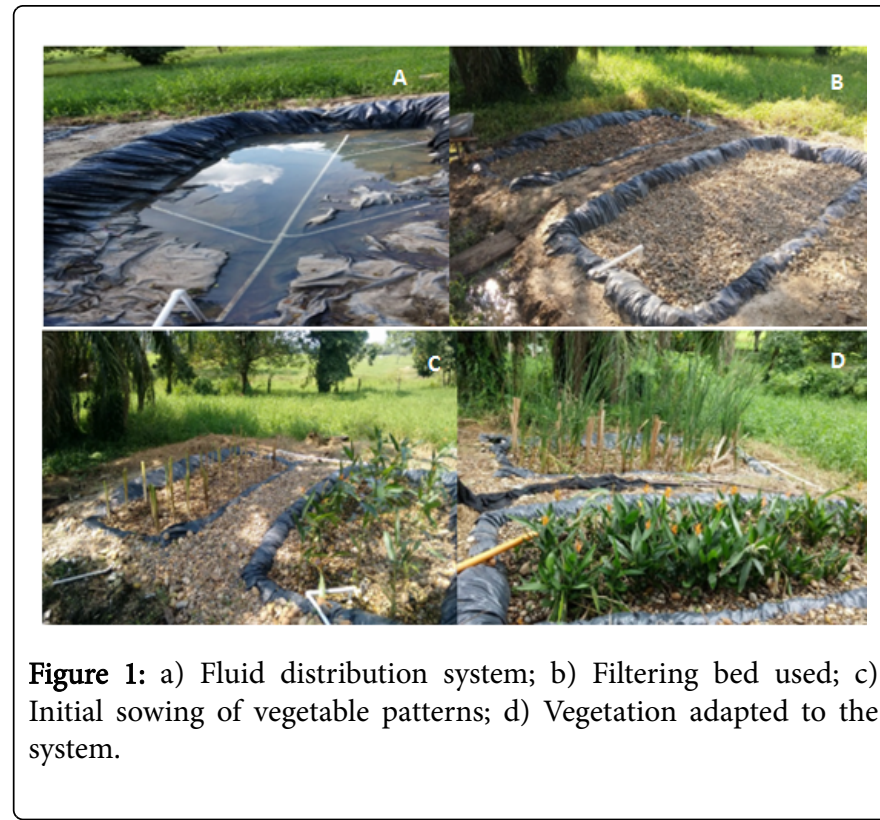

\section{Laboratory analysis for treated water}

The water samples were homogenized and characterized. The evaluation contemplated the pre-test and post-test analysis to determine and verify which of the systems obtained the greatest removal of organic matter. All the analyzes carried out were carried out following the protocols established by the APHA's Standard Methods for the Examination of Water and Wastewater (Standard Methods for the Examination of Institutional Waters and Waters). AWWA, WEF).

\section{Analysis of data}

The organic matter concentration data (COD and BOD5) are presented as mean +/- standard error. A univariate analysis was performed on the quantitative variables of the treatments applied and their respective target control. The analysis of measures of central tendency was determined with the mean, median, standard error and position with the interquartile range.

Statistical analysis was performed using Excel and PAST software.

\section{Results}

Once the adaptation time of the plants was finished, and the system was already doing the removal process, physical-chemical tests were made to determine the efficiency of the system, 3 composite samples were made in 3 different days of a week. Monday (A1), Wednesday (A2) and Friday (A3), before the entry to the system and after the exit of the system and took to laboratory (Tables 1 and 2).

\begin{tabular}{|l|l|l|l|l|l|l|}
\hline \multicolumn{2}{|l|}{ DBO5 } & DQO & SST & SSED & GA & pH \\
\hline Half & 4816.7 & 9530.7 & 4502.8 & 265.0 & 39.5 & $\begin{array}{l}6 . \\
9\end{array}$ \\
\hline Median & 6220.0 & 11555.0 & 5584.0 & 325.0 & 39.6 & $\begin{array}{l}7 . \\
0\end{array}$ \\
\hline $\begin{array}{l}\text { Standard } \\
\text { deviation }\end{array}$ & 2482.8 & 4818.7 & 2282.7 & 126.2 & 0.3 & $\begin{array}{l}0 . \\
2\end{array}$ \\
\hline
\end{tabular}


Citation: Cardozo JAQ, Zarta GAG, Nájera CDL, Martínez SSS (2018) Removal of Organic Matter Using Phytoextraction Technique with the Heliconia psittacorum and Typha angustifolia Species in Swine Production Systems. J Vet Sci Technol 9: 531. doi: $10.4172 / 2157-7579.1000531$

Page 3 of 5

\begin{tabular}{|l|l|l|l|l|l|l|}
\hline $\begin{array}{l}\text { Sample } \\
\text { variance }\end{array}$ & $\begin{array}{l}6164233 . \\
3\end{array}$ & 23220076.3 & 5210636.3 & 15925.0 & 0.1 & $\begin{array}{l}0 . \\
0\end{array}$ \\
\hline
\end{tabular}

Table 1: Results-Descriptive analysis tributary.

\begin{tabular}{|l|l|l|l|l|l|l|}
\hline \multicolumn{2}{|l|}{ DBO5 } & DQO & SST & SSED & GA & pH \\
\hline Half & 30.0 & 70.3 & 17.7 & 0.1 & 16.4 & 6.6 \\
\hline Median & 30.0 & 71.0 & 17.0 & 0.1 & 15.8 & 6.5 \\
\hline Standard deviation & 5.0 & 3.1 & 2.1 & 0.0 & 2.6 & 0.1 \\
\hline Sample variance & 25.0 & 9.3 & 4.3 & 0.0 & 6.5 & 0.0 \\
\hline
\end{tabular}

Table 2: Results-Descriptive analysis effluent.

\section{Comparative analysis}

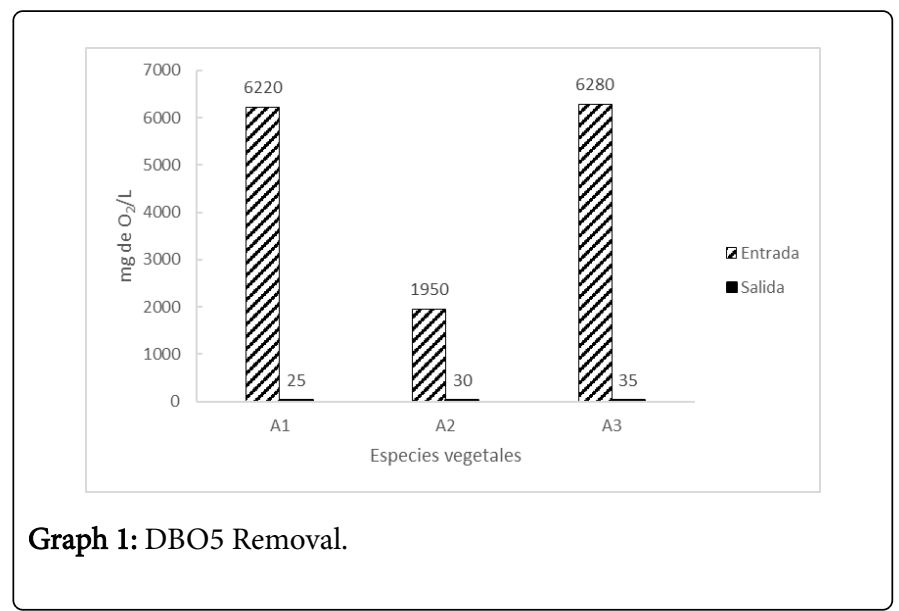

As it can be seen in Graph 1, the BOD5 at the entrance reached values of $6280 \mathrm{mg} \mathrm{O} / 2 / \mathrm{L}, 6220 \mathrm{mg} \mathrm{O} / \mathrm{L}$ and $1950 \mathrm{mg} \mathrm{O} / 2 / \mathrm{L}$; at the exit, after having had removals between $98 \%$ and $99 \%$, values of 25,30 and $35 \mathrm{mg} \mathrm{O} / 2$ were recorded, demonstrating the high efficiency of the treatment system.

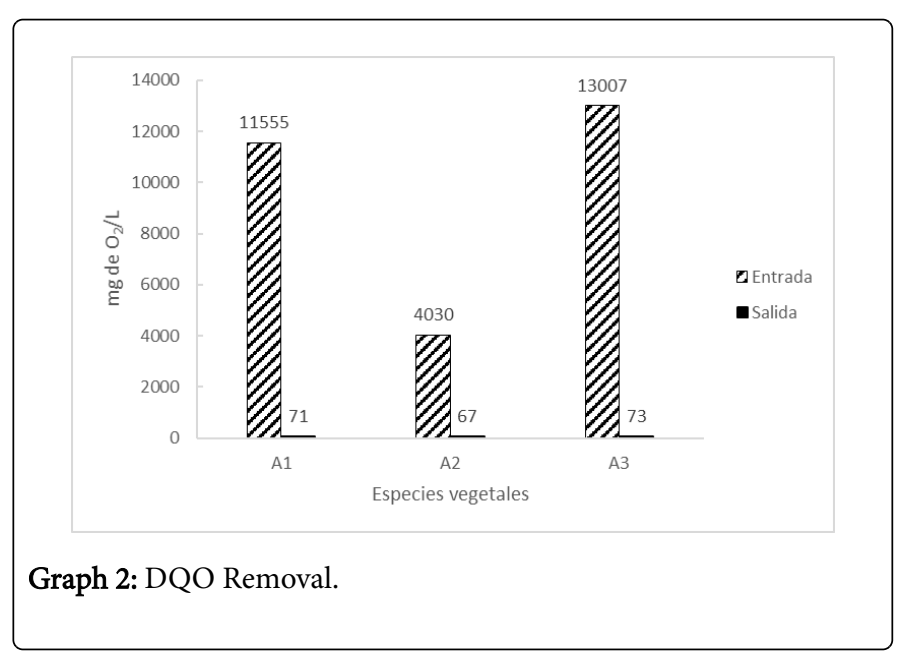

In Graph 2, it can be seen that in the three days of analysis, COD values were obtained at the inlet of $11555 \mathrm{mg} / \mathrm{l}, 4030 \mathrm{mg} / \mathrm{l}$ and 13007 $\mathrm{mg} / \mathrm{L}$, and values of $71 \mathrm{mg} / \mathrm{L}$ were recorded at the outlet. $67 \mathrm{mg} / \mathrm{L}$ and

$73 \mathrm{mg} / \mathrm{L}$, indicating, that the system in this parameter had a percentage of removal between $98 \%$ and $99 \%$.

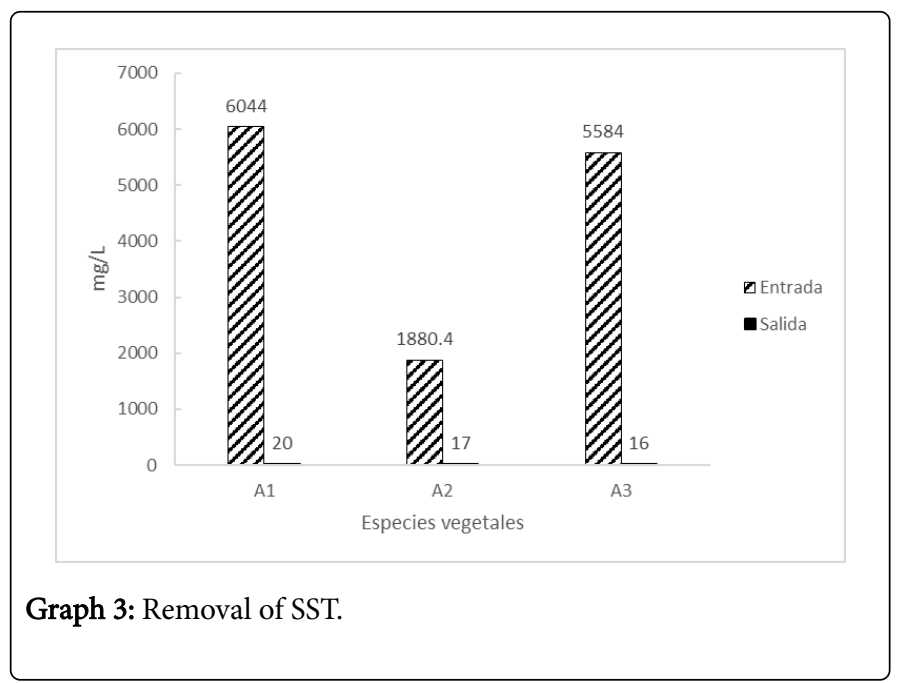

For the SST parameter, in Graph 3 the obtained values are recorded, in the input there were $6044 \mathrm{mg} / \mathrm{l}, 1880.4 \mathrm{mg} / \mathrm{L}$ and $5584 \mathrm{mg} / \mathrm{L}$; and at the outlet of $20 \mathrm{mg} / \mathrm{l}, 17 \mathrm{mg} / \mathrm{L}$ and $16 \mathrm{mg} / \mathrm{L}$, obtaining, removal percentages above $99 \%$.

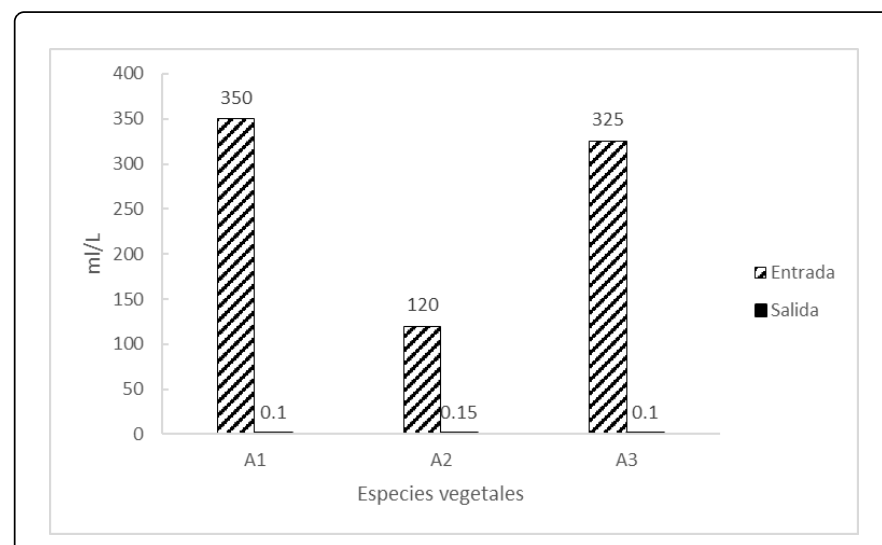

Graph 4: Removal SSED.

Graph 4 shows the SSED values contained in the water, which are $350 \mathrm{ml} / \mathrm{L}, 120 \mathrm{ml} / \mathrm{L}$ and $325 \mathrm{ml} / \mathrm{L}$, and at the outlet of $0.1 \mathrm{ml} / \mathrm{L}, 0.15$ $\mathrm{ml} / \mathrm{L}$ and $0.1 \mathrm{ml} / \mathrm{L}$; indicating a removal, of almost $100 \%$ of solids sedimentables (Graph 5). 
Citation: Cardozo JAQ, Zarta GAG, Nájera CDL, Martínez SSS (2018) Removal of Organic Matter Using Phytoextraction Technique with the Heliconia psittacorum and Typha angustifolia Species in Swine Production Systems. J Vet Sci Technol 9: 531. doi: 10.4172/2157-7579.1000531

Page 4 of 5

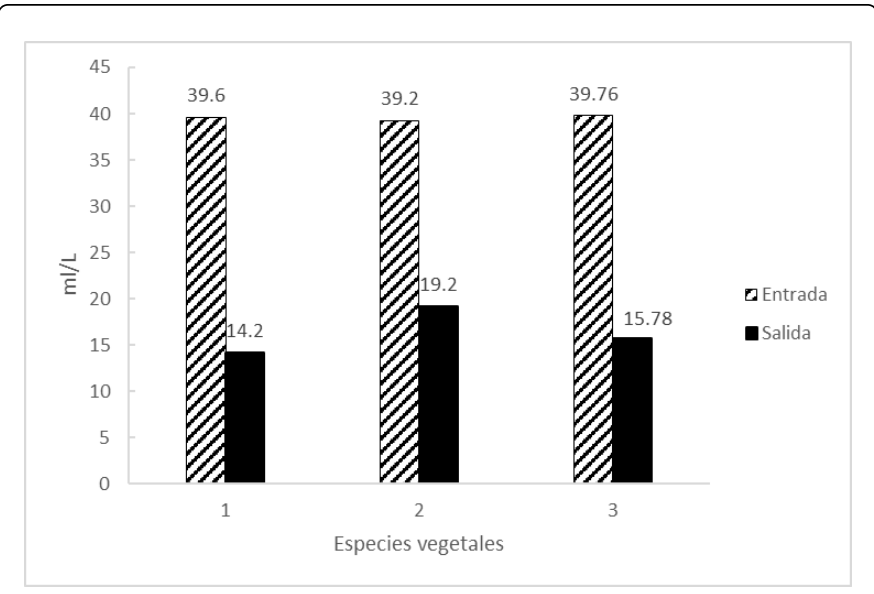

Graph 5: GA Removal.

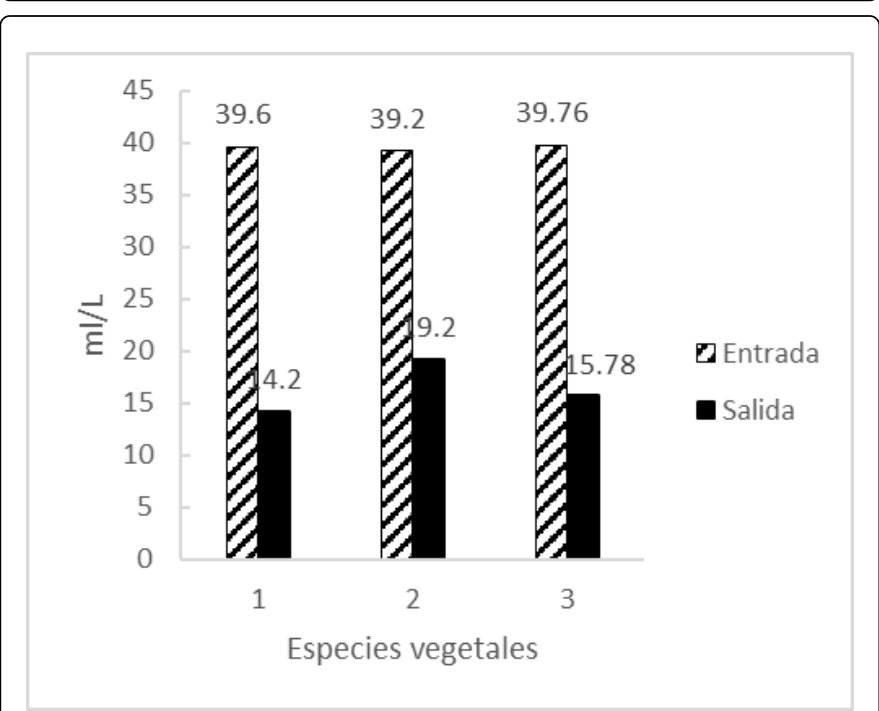

Graph 6: Registered pH.

As can it be seen in Graph 6, the $\mathrm{pH}$, both, at the entrance and at the exit, along the three days of the study, it does not show significant changes, presenting a minimum value of 6.72 at the entrance and 6.52 at the exit; and maximum values of 7.11 at the entrance and 6.62 at the output.

The results show percentages of removal of very significant measured variables that are above $96 \%$ in all parameters obtained. Graph 7 shows the efficiency obtained by the system that combines two emergent vegetation patterns in an artificial wetland system, through the functional features of the roots of the species used, as a means of transport and adsorption of pollutants of interest in the investigation.

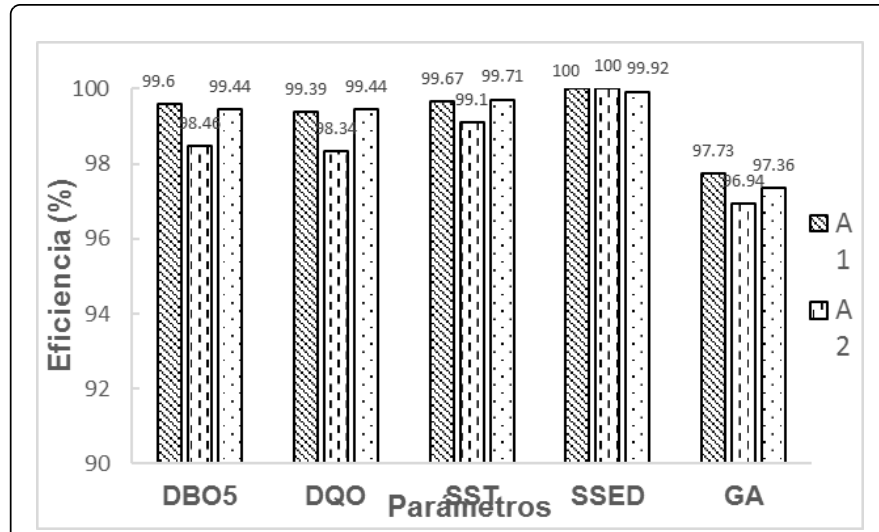

Graph 7: Removal curve of the measured variables.

\section{Discussion}

The decomposition or reduction of organic matter contained in the wastewater is mainly due to the action of anaerobic microorganisms, that is, they are dependent on the available oxygen, in conjunction with the plants, which are responsible for injecting oxygen into the system, propitiating the growth of these microorganisms, and in addition, by their processes of obtaining energy (photosynthesis) they use the nutrients that make up the organic matter, thus carrying out a process of phyto depuration of water.

This research is an integrated system for the purification of wastewater, which is composed by a system of screening (pretreatment), sedimentation tank (primary treatment) and artificial wetlands of subsurface flow (secondary treatment), being of great importance for the process, since it is a biological system, in which the spices Heliconia psittacorum and Typha angustifolia were used.

As can be seen in the tables and graphs, the system showed decontamination ranges between $96 \%$ and $99 \%$ in BOD5, DQP, SST, SSDE, and GA, complying with the environmental regulations of dumping (Resolution 631/2015) and verifying that This biological treatment system is highly effective for wastewater originating from livestock activities.

Several investigations have been conducted to evaluate the efficiency of artificial wetlands in the treatment of wastewater, such as the one developed by Meneses and Devia entitled "Evaluation of the species Scirpus californicus and Typha angustifolia in an artificial wetland of horizontal type and subsurface flow at scale pilot for the removal of organic matter in wastewater, at the Santa Lucia Barrancabermeja, Santader research center, "where removal of BOD5 and COD of $86.30 \%$ with Typha angustifolia and $86.52 \%$ with Scirpus californicus, in similar climatic conditions but in a field experimental phase on a smaller scale, it is intuited with this research that the patterns of organic load removal are optimal and that the planting density of the species and the adaptation times can directly influence the reduction of organic load, measured for these two investigations by the BOD5 and the COD.

In the research called "Evaluation of an artificial wetland of subsurface flow in the treatment of wastewater generated in the university college of Antioquia, Colombia." De Bedoya et al. [2]. The highest levels of COD removal (70.4\%), BOD5 (96.7\%) and SST 
Citation: Cardozo JAQ, Zarta GAG, Nájera CDL, Martínez SSS (2018) Removal of Organic Matter Using Phytoextraction Technique with the Heliconia psittacorum and Typha angustifolia Species in Swine Production Systems. J Vet Sci Technol 9: 531. doi: $10.4172 / 2157-7579.1000531$

Page 5 of 5

(81.4\%), were obtained in the wetland that contained the species $T$. latifolia, demonstrating the efficiency of the emergent species in this type of treatment systems. Castañeda and Flores in Mexico [3], obtained removal efficiencies in BOD5 $=86 \%, \mathrm{NT}=64 \%, \mathrm{PT}=68 \%, \mathrm{G}$ and $\mathrm{A}=60 \%$, using common reed (Phragmites australis), gladiolus (Gladiolus spp) and totora (Typha latifolia), with retention times of three, five and seven days, establishing that the times of greatest removal by the seedlings was in the warmer months, where the temperature of Mexico reached 26 to $27^{\circ} \mathrm{C}$.

In another study Solis et al. Used vegetation Paspalum paniculatum, reporting efficiencies for turbidity and color of 95 and 99\%, Typha latifolia with a turbidity and color of 98 and $90 \%$ respectively, COD in 94.38 and $95.22 \%$ and with times of 5-day hydraulic retention with free-flowing and subsurface-flow wetlands; and Paredes [4] evaluated artificial wetlands planted with Heliconia $s p$, obtaining percentages of removal of BOD5, COD and SST of $96 \%, 93 \%$ and $82-87 \%$ respectively. At the local level we can find the publication of Quintero that contains the results of a research developed in the city of Barrancabermeja and demonstrates percentages of removal of biological demand for oxygen BOD5 of more than $87 \%$ for an artificial wetland pilot that I analyze two species in different systems the sp. Heliconia psittacorum and the Lemna minor [5].

Unlike some of the previously mentioned works, which only evaluated the efficiency of artificial wetlands in experimental and/or pilot systems, in this research a complete wastewater treatment system was designed and implemented, which is composed of a screening system, a sedimentation tank and artificial wetlands of subsurface flow; therefore, percentages of removal of BOD, COD and Solids are recorded, a little higher, but which maintain the dynamics and tendency of the studies carried out.

The removal or diminution of organic matter from water, which, since the pre-treatment (screening) is already beginning to diminish, being retained in the grids; in the settler the concentration is lowered considerably; and finally the wetlands, by the action of the plants, which need nutrients for their photosynthesis process and find them in the concentrations of organic matter in the water; and of microorganisms contained in biofilms of the filter bed or support medium (gravel), which decompose the organic matter of water for their metabolic processes.

In the sampling time, it was possible to show the fluctuations of the concentrations due to two factors, the first on the days of washing the productive area, in the middle of the week no washing is carried out, so the flow decreases and the second at the moment of the sample flow was very low, that is, the washing was already over, so it is possible that much of the organic matter had already entered the system.

It is important to note that the artificial wetlands had an accelerated reproduction of the plants, therefore higher removal levels were obtained, the planting density was 30 seedlings with a retention time of 12 hours.

\section{Conclusion}

The values of the wastewater from the Academic Swine Research Nucleus (NAIP) of MVZ, obtained during the diagnostic phase, for the case of BOD5, COD and SST, exceeded the permissible limits stipulated in Resolution 631/2015 for $10 \mathrm{mg} \mathrm{O}_{2} / \mathrm{L}, 250 \mathrm{mg} \mathrm{O}_{2} / \mathrm{L}$ and 27 $\mathrm{mg} / \mathrm{L}$ respectively; while in the analyzes carried out once the system was implemented to determine its efficiency, at the entrance of the system the BOD5, COD and SST exceeded the limits by $5830 \mathrm{mg} \mathrm{O}_{2} / \mathrm{L}$, $12107 \mathrm{mg} \mathrm{O} / 2$ and $5644 \mathrm{mg} / \mathrm{L}$ respectively, obtaining this exponential increase as a consequence of the increase in the pig population.

The realization of the design of a biological system for the treatment of these wastewater is presented as a viable alternative, both from the economic point of view, since the maximum cost of this system did not exceed the value of one (1) million pesos, because both the vegetation and the gravel (Wetlands) are in our region in a natural and abundant way; its construction, operation and maintenance are quite understandable to anyone and does not require special attention; and for its high efficiency with removal rates between $96 \%$ and $99 \%$.

The implementation of the biological system, showed its great importance for the reduction of the polluting load of the NAIP effluent, with removal rates between $96 \%$ and $99 \%$ throughout the 6 months of study, decreasing the levels of BOD5 and COD $6280 \mathrm{mg}$ $\mathrm{O}_{2} / \mathrm{L}$ and $13007 \mathrm{mg} \mathrm{O} / 2$ up to $25 \mathrm{mg} \mathrm{O} / 2$ and $35 \mathrm{mg} \mathrm{O}_{2} / \mathrm{L}$ respectively, thus complying with the environmental regulations of vertimientos.

With the results mentioned above, it is demonstrated how highly efficient the plants Typha angustifolia and Heliconia psittacorum are in the use of these biological systems of wastewater treatment, which although it is true in this study, were not evaluated individually to determine the level of removal of each species, was evidenced as a complete system with these two species works efficiently.

\section{Acknowledgements}

To the University Institute of La Paz-UNIPAZ, The Research Group GIAS, the Nucleus of Research in Environmental Biotechnology-NIBA and the semillero of Research Consciousness Green - Colombia.

\section{References}

1. Ministry of Environment (2002) General Environmental Management Sector. Environmental guide for the porcicola subsector.

2. Perez B, Calle JR (2014) Evaluation of an artificial wetland of subsurface flow in the treatment of wastewater generated in the university college of Antioquia, Colombia. International Journal of Environmental Pollution 30: 1-4.

3. Aldo C, Hugo F (1990) Domestic wastewater treatment through typical macrophyte plants in Los Altos de Jalisco, Mexico. Paakat Journal of Technology and Society 3: 2013-2014.

4. Paredes D, Laura V (2014) Removal of pollutants in the stabilization of wetlands constructed of vertical flow, planted with heliconia (sp), for the treatment of domestic wastewater. Degree work (Chemical Technology). Technological University of Pereira. School of Technology School of Chemistry Chemical Technology Program, Pereira.

5. Quintero M, Edwin F, Cogollo D, Hernán A (2016) Evaluation of the species Scripus Californicus and Typha Angustifolia in an artificial wetland of horizontal type and subsurface flow at a pilot scale for the removal of organic matter in wastewater, at the Santa Lucia Research Center Barrancabermeja, Santander. Degree work (Environmental and Sanitation Engineering). University Institute of Peace-UNIPAZ. School of Environmental Engineering. Environmental Engineering and Sanitation Program, Barrancabermeja. 